\title{
Institutional Analysis of Adoption of Agroforestry Practices in the Eastern Cape Province of South Africa
}

Mulatu F. Zerihun, Tshwane University of Technology, South Africa

\begin{abstract}
Agroforestry practices are innovations developed in response to problems associated with inappropriate land use practices. The latter refers to the use of agricultural land for non-agricultural purposes because of an increase in urbanisation, rapidly developing industry, and investments, and, finally, gaps in laws and regulations (Cengiz, 2013). Agroforestry practices are land-based economic development strategies with a perceived positive role in supporting rural livelihoods. Using a logistic regression model with cross-sectional data, this study explores the impact of institutional factors and incentive mechanisms that affect the adoption of agroforestry innovations. The study finds that a larger number of extension services, access to credit, access to extension, information exchange among farmers, trust in local institutions, active participation in social groups and organisations, and prior exposure to agricultural technologies are the variables that positively affect the adoption of agroforestry innovations in the study area. These findings have policy implications in promoting integrated rural development in the Eastern Cape Province of South Africa.
\end{abstract}

Keywords: adoption, agroforestry, innovation, institutions, logit model, odds ratios, South Africa

\section{Introduction}

In this paper agroforestry is defined as "land use that involves deliberate retention, introduction, or mixture of trees or other woody perennials in crop or animal production fields to benefit from the resultant ecological and economic interactions" (MacDicken \&Vergara, 1990, p. 382). The prevailing environmental distress in South Africa, particularly in rural areas, calls for the adoption of integrated sustainable rural development strategies like agroforestry practices. The experiences from other countries show that agroforestry can contribute to sustainable rural development as a natural resources' management technology with proven positive impacts on the economy of rural households (Van Noordwijka, 2019). Following a gradual evolutionary process, agroforestry has become an interdisciplinary science with wider application in the areas of socio-economic, ecological, and environmental development (Lassoie \& Buck, 2000; Food \& Agricultural Organisation [FAO], 2013). Although agroforestry practices were introduced to South Africa as early as 1887 (Nair, 1993), the sub-sector has not been well developed due to weak institutional support and poor incentive mechanisms. The Eastern 
Cape Province, one of the rural provinces in South Africa, was selected for the study due to its vast potential for agricultural activities and agroforestry practices.

Smallholder agriculture dominates the landscape of the developing world. Small farmers are a key group requiring attention in agricultural and rural development. Smallholders will not be able to solve the challenge of sustainable agriculture by themselves. Efforts are required from both the public and the private sector and effective public-private partnerships along the agricultural and food value chain. Sustainable agriculture also calls for the integration of modern, science-based technologies with local knowledge, and the participatory involvement of farmers in the technology process. Contrary to what is known about most of the countries in the Southern African Development Community (SADC) region, the practice of agroforestry is not well developed in South Africa. This problem is directly related to the dualistic nature of the agriculture sector in the country and bias against smallholder farmers in favour of commercial monoculture farming. Agroforestry is a multiple land use system where agricultural crops and woody perennials are grown on the same land management unit (Owunubi \& Otegbeye, 2012; Brown, Mille, Ordonez \& Baylis, 2018). Traditional agroforestry systems have been practised for millennia by agrarian-based societies throughout the world (Garrity, 2006). These systems demonstrate an ability to conserve biodiversity, suppress insect pests and weeds better than monoculture agricultural systems (Sileshi, Akinnifesi, Ajayi \& Place, 2009). Recently, agroforestry has progressed to become one of the science-based pathways for achieving important objectives in natural resource management and poverty alleviation (Owunubi \& Otegbeye, 2012; Van Noordwijka, 2019). The objective of this study is to explore institutional factors and incentive mechanisms that affect the adoption of agroforestry practices in the Eastern Cape Province of South Africa. The study hypothesises that institutional factors and existing household incentive mechanisms have statistically significant impacts on the adoption of agroforestry practices in the study areas. These hypotheses are proved based on binary logistic regression analysis.

Growth and sustainability of the South African agricultural sector has been challenged by factors such as decreasing soil quality and changing weather patterns, among others (Department of Agriculture, Forestry and Fisheries [DAFF], 2012). A significant proportion (i.e. slightly less than 40\%) of the South African population is residing in rural parts of the country. It is widely believed that land-based economic development strategies play a major role in livelihood improvement and economic development in South Africa (Shackleton, Shackleton \& Cousins, 2001; Lahiff, 2002; Manona, 2005). Moreover, South Africa's new growth path document perceives the agricultural sector as a major contributor to job creation and rural development (Sibisi, 2011).

Limitations in this study are linked to the unavailability of data pertaining to different types of agroforestry practices in the study areas; specific factors affect a specific type of agroforestry practice. Collection of longitudinal data on various types of agroforestry technology adoption would be useful for understanding appropriate agroforestry technologies for specific provinces or agro-climatic regions in the country. This would further speed up improved agroforestry adoption and indicate areas for effective policy intervention by government agencies and NGOs. A further limitation is the lack of a qualitative, descriptive account of agroforestry 
practices in the area. Future studies in the area could consider these missing aspects of this study.

The remaining sections of the paper are organised as follows. Section two briefly reviews the concept of agroforestry practices and the roles of institutions in promoting such practices. Section three presents the data and methodology used in the study while section four presents discussions on relevant issues in the study areas and empirical findings of the study. The last section concludes the study.

\section{Literature review}

\section{Agroforestry practices and the role of institutions}

The adoption of agroforestry technology can be associated with the concept of induced innovation, which was influenced by Boserup's (1965) analysis of agricultural growth. Boserup (1965) showed that as population densities rise, demand for agricultural products increases, and the resulting land pressures induce adoption of technological and institutional practices to intensify land use. Basically, the scarcity of land relative to labour and/or capital induces investment in additional labour or capital inputs to maintain or increase agricultural production. Agroforestry practices are considered 'induced innovations' as they have been developed in different parts of the word in response to land use pressures in an attempt to address deteriorating environmental conditions and are common to innovation decision processes in any sector (Reed, Dougill \& Taylor, 2007; Sahoo,Wani \& Satpathy, 2020).

In terms of climate change and the global carbon cycle, agroforestry is beneficial for at least two reasons. Firstly, trees fix and store carbon from the atmosphere. Because trees are perennial plants they can function as active carbon sinks for many years; trees continue to store carbon until they are cut or die. Secondly, agroforestry can reduce the need to clear forests for agriculture by providing an alternative to shifting cultivation (Sanchez \& Jama, 1990). A key structural attribute of agroforestry is multiple vertical strata that occupy space efficiently and provide a range of growing conditions. The tree canopy provides shade and reduces evaporation from the soil. This shading effect also reduces temperature and provides a more moderate microclimate for crop growth. The tree canopy further provides shelter from wind, protects the soil from the impacts of heavy rain and helps to reduce soil erosion. Leaf litter acts as mulch and reduces both evaporation and surface runoff and erosion. Incorporation of leaves into soil adds organic matter and improves soil quality. Below the ground, tree roots penetrate to deeper soil layers than crop roots and bring nutrients to the surface via leaf fall. Nitrogen-fixing agroforestry tree species capture nitrogen, a key nutrient from the atmosphere and make it available to crop plants. The economic benefits of agroforestry derive from diversification of outputs, spreading risk, and, in many cases, increasing physical output (MacDicken \&Vergara, 1990). These characteristics may also make agroforestry systems more resistant to climate change than mono cropping systems. There are multidimensional aspects to agroforestry which require in-depth scientific analysis for the extensive application of agroforestry practices in sustainable land management endeavours. 
Table 1 Major agroforestry practices in the tropics

\begin{tabular}{|c|c|}
\hline $\begin{array}{l}\text { Type of agroforestry } \\
\text { practice }\end{array}$ & Brief description \\
\hline Taungya & $\begin{array}{l}\text { Agricultural crops grown during the early stages of forest plantation } \\
\text { establishment }\end{array}$ \\
\hline Home gardens & $\begin{array}{l}\text { Intimate, multi-storey combinations of a variety of trees and crops in } \\
\text { homestead gardens; livestock may or may not be present }\end{array}$ \\
\hline Improved fallow & $\begin{array}{l}\text { Fast growing, preferably leguminous woody species planted during the } \\
\text { fallow phase of shifting cultivation; woody species improve soil fertility } \\
\text { and may yield economic products }\end{array}$ \\
\hline Multipurpose trees & $\begin{array}{l}\text { Fruit and other trees randomly or systematically planted in cropland or } \\
\text { pasture for the purpose of providing fruit, fuel wood, fodder, and timber, } \\
\text { among other services, on farms and rangelands }\end{array}$ \\
\hline $\begin{array}{l}\text { Plantation-crop } \\
\text { combinations }\end{array}$ & $\begin{array}{l}\text { Integrated multi-storey mixtures of tree crops (such as coconut, cacao, } \\
\text { coffee, and rubber), shade trees, and/or herbaceous crops }\end{array}$ \\
\hline Silvopasture & $\begin{array}{l}\text { Combining trees with forage and livestock production, such as grazing } \\
\text { in existing forests; using trees to create live fences around pasture; or to } \\
\text { provide shade and erosion control }\end{array}$ \\
\hline $\begin{array}{l}\text { Shelterbelts and } \\
\text { windbreaks }\end{array}$ & $\begin{array}{l}\text { Rows of trees around farms and fields planted and managed as part } \\
\text { of crop or livestock operations to protect crops, animals, and soil from } \\
\text { natural hazards including wind, excessive rain, seawater, or floods }\end{array}$ \\
\hline Alley cropping & $\begin{array}{l}\text { Fast-growing, preferably leguminous woody species in single or grouped } \\
\text { rows are applied as mulch into the agricultural production alleys to } \\
\text { increase organic matter and nutrients and/or are removed from the field } \\
\text { for other purposes such as animal fodder }\end{array}$ \\
\hline
\end{tabular}

Source: Adapted from Alavalapati \& Nair (2001) and Alavalapati, Mercer \& Motambault (2004)

\section{Factors affecting adoption of agroforestry practices}

Because of its ecological, economic, and social attributes, agroforestry is widely recognised as a sustainable land management practice particularly in the tropics (Lassoie \& Buck, 2000; FAO, 2013). In this section we review existing literature on factors, incentives, mechanisms, and processes linked to the adoption of agroforestry. There are two types of studies associated with the analysis of agroforestry technologies: ex-ante and ex-post studies. Ex-ante studies of the profitability, feasibility and acceptability of experimental agroforestry systems are essential for researchers in helping design appropriate systems, for development agencies in determining how and where to allocate scarce programme funds, and for farmers as they experiment and test new systems as part of the adoption process. Ex-post studies are equally important for predicting which segments of society will adopt at various times in the adoption cycle, for estimating the livelihood and equity impacts of agroforestry projects, and for designing effective policies to encourage adoption by target populations. Pattanayak, Mercer, Sills and Yang (2003) reviewed 
ex-post studies on adoption of agricultural and forestry technology by smallholder farmers and found that five categories of factors explain technology adoption: household preferences, resource endowments, market incentives, biophysical factors, and risk and uncertainty. Likewise, in a comparison of tree planting between Brazil and Panama, Simmons, Walker and Wood (2002) found that institutional variables were more important than household preference variables.

\section{Methodology}

\section{Study area and the data}

The Eastern Cape Province is situated in the south-eastern part of South Africa. The northwest part of the province borders on KwaZulu-Natal and touches the southern tip of the Drakensberg range. Mountains and hills are common in the southern parts of the province, although the Karoo is generally flat. The dominant land use in the majority of the Eastern Cape is livestock grazing, along with dry land agriculture in the eastern section of the province. Figure 1 shows the study area.

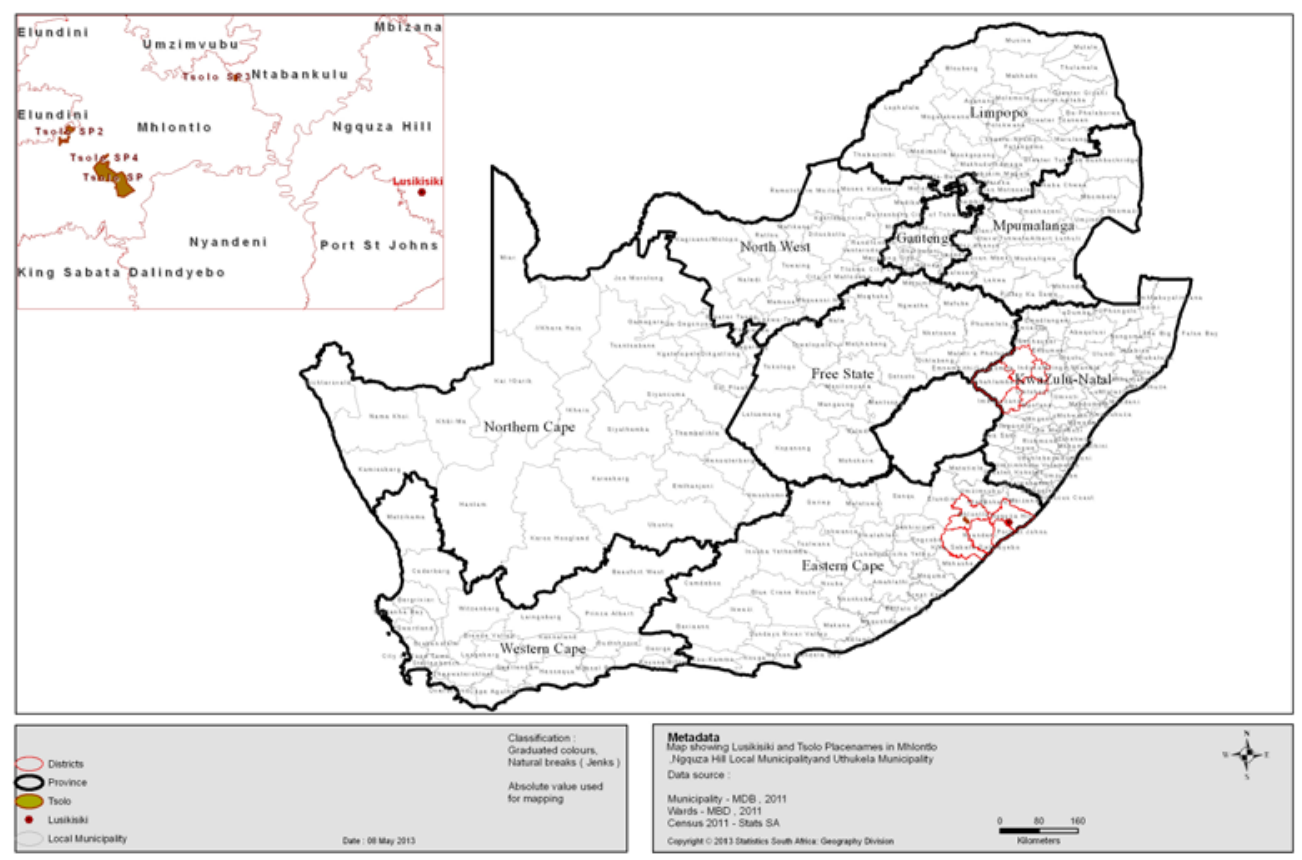

Figure 1 Map showing study sites (Source: StatSA - customised for study)

Agriculture in the Eastern Cape is dominated by intensive beef and fruit farming in the south-western parts, and subsistence farming (mainly cattle, maize and sorghum) in the north-eastern regions. The southern coastal area is conducive to forestry. The Eastern Cape faces several environmental threats, chiefly land degradation. It exhibits high levels of soil 
degradation, particularly in commercial farmland areas. In other areas, the thicket biome is threatened by invasive alien species and overgrazing by domestic herbivores.

Quantitative data was collected from Tsolo and Lusikisiki Magisterial Districts of the Eastern Cape Province by use of a pre-tested, validated, and standardised questionnaire. The survey was conducted from December 2011 to June 2012. These two sites were selected for their noticeable agroforestry practices. See Figure 1 for the geographical location of the study sites. A total of 300 households were surveyed. Mixtures of purposive and systematic random sampling methods were used to draw the final sample. Table 2 presents the descriptive statistics of the dependent and explanatory variables in the regression analysis. The dependent variable for both groups of explanatory variables used in the logit regression was the dichotomous variable of agroforestry adoption. The value ' 1 ' indicates the respondent had adopted any one of those agroforestry practices mentioned in Table 1.

Table 2 Descriptive statistics of variables included in the analysis

\begin{tabular}{|c|c|c|c|}
\hline $\begin{array}{l}\text { Explanatory } \\
\text { Variable Code }\end{array}$ & Variable Description & Mean & $\begin{array}{c}\text { Std. } \\
\text { Deviation }\end{array}$ \\
\hline \multicolumn{4}{|c|}{ Institutional variables } \\
\hline WAL & Women's access to land i.e. land ownership & 0.86 & 0.345 \\
\hline PRAs & Participation in the religious institutions & 1.53 & 1.186 \\
\hline IEWF & Information exchange among farmers & 1.92 & 0.796 \\
\hline TEWF & $\begin{array}{l}\text { Technical exchange with other farmers e.g. } \\
\text { farm equipment }\end{array}$ & 2.02 & 0.892 \\
\hline TP & $\begin{array}{l}\text { Trend of participation in groups or } \\
\text { organisations among household members }\end{array}$ & 0.37 & 0.484 \\
\hline TA & Trust in local associations /organisations & 0.44 & 0.497 \\
\hline Sample Size (N) & \multicolumn{3}{|l|}{300} \\
\hline Dependent variable & \multicolumn{3}{|c|}{ Adoption of agroforestry technologies: if "yes" 1 , if "no" 0} \\
\hline \multicolumn{4}{|c|}{ Household incentive mechanisms } \\
\hline $\mathrm{AE}$ & Access to extension & .81 & .393 \\
\hline FES & Frequency of extension services & 1.35 & 1.039 \\
\hline$A C$ & Access to credit & .64 & .480 \\
\hline PEAT & Prior exposure to agricultural technologies & .40 & .654 \\
\hline Agroforestry PS & $\begin{array}{l}\text { Agroforestry products harvested/services } \\
\text { generated }\end{array}$ & .52 & .500 \\
\hline 10 & Incentive obtained & .24 & .430 \\
\hline RI & Risks involved & .43 & .496 \\
\hline Valid N & \multicolumn{3}{|l|}{300} \\
\hline Dependent variable & \multicolumn{3}{|c|}{ Adoption of agroforestry technologies: if "yes" 1 , if "no" 0} \\
\hline
\end{tabular}

Source: Computed from survey data 


\section{Empirical model: Logit model specification}

Most agroforestry adoption studies have relied on logit or probit models to analyse dichotomous or binary adoption decisions in which the dependent variable is binary ( 1 if adopts, 0 otherwise). This study used a more realistic logit model that assumed logistic distribution unlike the probit model that assumes normal distribution to find the best fitting and most parsimonious yet technically reasonable model. Logit models employ logit regressions with correction for heteroskedasticity. Heteroskedasticity usually arises in cross-section data where the scale of the dependent variable and the explanatory power of the model tend to vary across observations (Green, 2002; Klieštika, Kočišováa \& Mišankováa, 2015). For more details on the benefits and limitations of logit model see Gujarati (2004, pp. 596-609).

The logit modelling approach considers adoption as a dichotomous independent variable, which takes ' 1 ' if adoption is present and ' 0 ' otherwise. The model produced in logistic regression is non-linear and the outcome variable, $\mathrm{Y}$, is the probability of having one outcome or another based on a non-linear function of the best linear combination of predictors, with two outcomes. Following a logistic regression model (applied by Christensen, 1997; Peng \& So, 2002; Agresti \& Finlay, 2009; Kabwe, 2010; Zerihun, 2014) we have:

$$
\ln \left(\frac{\pi}{1-\pi}\right)=\log (\text { odds }) \Rightarrow \log Y=\alpha+\beta X
$$

When we take the antilog on both sides of equation (1), we derive the equation to predict the probability of the occurrence of the outcome of interest as shown in equation (2):

$$
\pi=P(Y)=\frac{e^{\alpha+\beta \chi}}{1+e^{\alpha+\beta \chi}}
$$

where

$\pi$ is the probability of the outcome of interest ( $\mathrm{Y}=1$ );

$\alpha$ is the Y-intercept (constant of the equation);

$\beta_{i}$ are the regression coefficients of the explanatory variables;

$X_{i}$ are a set of predictors; and

$e$ is the base of the system of the natural logarithms.

$$
\begin{cases}\text { The dependent variable } Y_{1 i}=\begin{array}{l}
0 \text { if household has not adopted agroforestry technologies } \\
1 \text { if household has adopted agroforestry technologies }
\end{array}\end{cases}
$$

Finally, taking the log of equation (2) we have the following logit model for estimating coefficients to find the best linear combination of predictors to maximise the likelihood of obtaining the observed outcome frequencies,

$$
\ln \left(\frac{P(Y=1)}{P(1-P(Y=1)}\right)=Y_{1 i}=\alpha^{*}+\beta_{1}^{*} \chi_{1}+\beta_{2}{ }^{*} \chi_{2}+\ldots \beta_{n}{ }^{*} \chi_{n}
$$




\section{Discussion}

\section{Land tenure types in the study areas}

As shown in Figure 2, in Tsolo large land size dominates followed by a category with land size less than one hectare and then medium land size (i.e.2ha). However, in Lusikisiki households a small land size dominated.

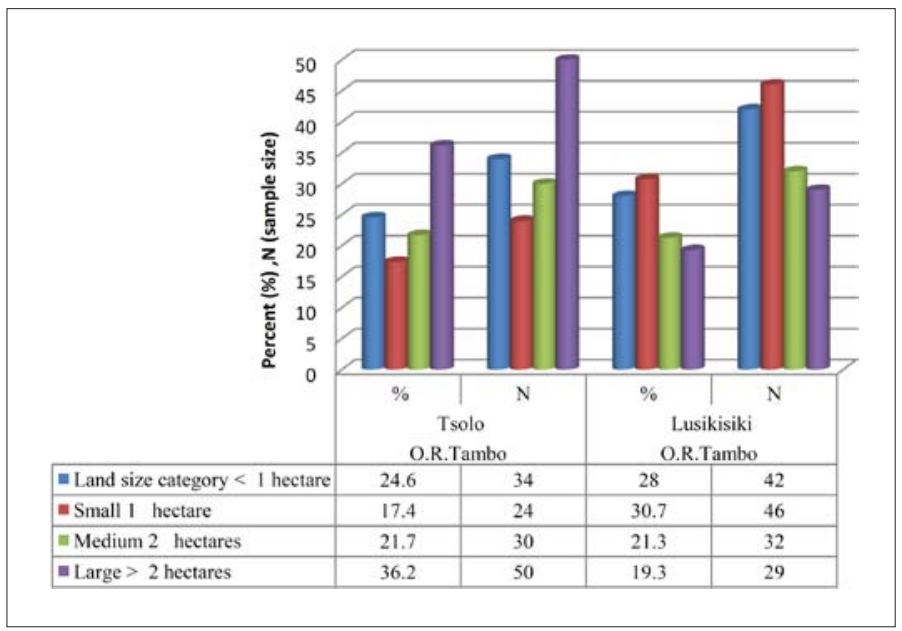

Figure 2 Land size categories in Tsolo and Lusikisiki Magisterial Districts (Source: Computed from survey data)

As indicated in Table 3, when we consider the age group of the respondents, $66.7 \%$ are in the age group 20-29 years and own agricultural land less than one hectare. This age group also owns the highest percentage (33.3\%) of land that is one hectare. In the two hectares category, the age group 50-59 years possessed $27.7 \%$ of the land. Of the 60-69-year-old respondents, $32.8 \%$ owned the large land size category of two hectares and larger.

Table 3 Agricultural land size by age group

\begin{tabular}{|c|c|c|c|c|c|c|c|c|c|c|c|c|c|c|}
\hline \multirow{2}{*}{$\begin{array}{l}\text { Land size } \\
\text { category }\end{array}$} & \multicolumn{2}{|c|}{$\begin{array}{l}20-29 \\
\text { years }\end{array}$} & \multicolumn{2}{|c|}{$\begin{array}{l}30-39 \\
\text { years }\end{array}$} & \multicolumn{2}{|c|}{$\begin{array}{l}40-49 \\
\text { years }\end{array}$} & \multicolumn{2}{|c|}{$\begin{array}{l}50-59 \\
\text { years }\end{array}$} & \multicolumn{2}{|c|}{$\begin{array}{l}60-69 \\
\text { years }\end{array}$} & \multicolumn{2}{|c|}{$\begin{array}{c}70+ \\
\text { years }\end{array}$} & \multicolumn{2}{|c|}{ Total } \\
\hline & $\%$ & $\mathrm{~N}$ & $\%$ & $\mathrm{~N}$ & $\%$ & $\mathrm{~N}$ & $\%$ & $\mathrm{~N}$ & $\%$ & $\mathrm{~N}$ & $\%$ & $\mathrm{~N}$ & $\%$ & $\mathrm{~N}$ \\
\hline$<1$ ha & 66.7 & 2 & 33.3 & 8 & 31.4 & 11 & 26.6 & 25 & 18.8 & 12 & 25.0 & 17 & 26.0 & 75 \\
\hline 1 ha & 3.3 & 1 & 25.0 & 6 & 28.6 & 1 & 1 & 14 & 26.6 & 17 & 3 & 22 & 2 & 0 \\
\hline 2 ha & .0 & 0 & 20.8 & 5 & 14.3 & 5 & 27.7 & 26 & 21.9 & 14 & 17.6 & 12 & 21.5 & 62 \\
\hline$>2$ ha & .0 & u & 20.8 & $J$ & 22.9 & 0 & 29.8 & 28 & 32.8 & 21 & 25.0 & 17 & 27.4 & 79 \\
\hline Total & 100 & 3 & 100 & 24 & 100 & 35 & 100 & 94 & 100 & 64 & 100 & 68 & 100 & 288 \\
\hline
\end{tabular}

Source: Computed from survey data Note: Percent (\%), N (sample size) 
Respondents were asked how they acquired their land and to state the land tenure situation in their localities. These questions are relevant due to the fact that tree planting is a long term investment which requires tenure security. Farmers may be reluctant to invest on their land to conserve it if they are uncertain about future rights to use it. On the other hand, a secure tenure system could lead to better land management technologies, which would improve soil quality and boost agricultural productivity. Many empirical studies claim that secured land rights create an essential economic incentive that enhance long-term land investment, which affects soil fertility and hence significantly influences agricultural productivity. However, some studies claim that land tenure security and/or insecurity are not significant for determining long-term land investment and thereby agricultural productivity. For instance, empirical findings by Brasselle, Gaspart and Platteau (2002) using household data from Burkina Faso cast doubt on the systematic influence of land tenure security on long-term and investment. In this study, as shown in Figure 3, the most frequent land acquiring modality is inheritance through communal ownership, followed by permission to use (user-right) and purchase. Inheritance was dominant in Tsolo while permission from local chiefs to use land was dominant in Lusikisiki.

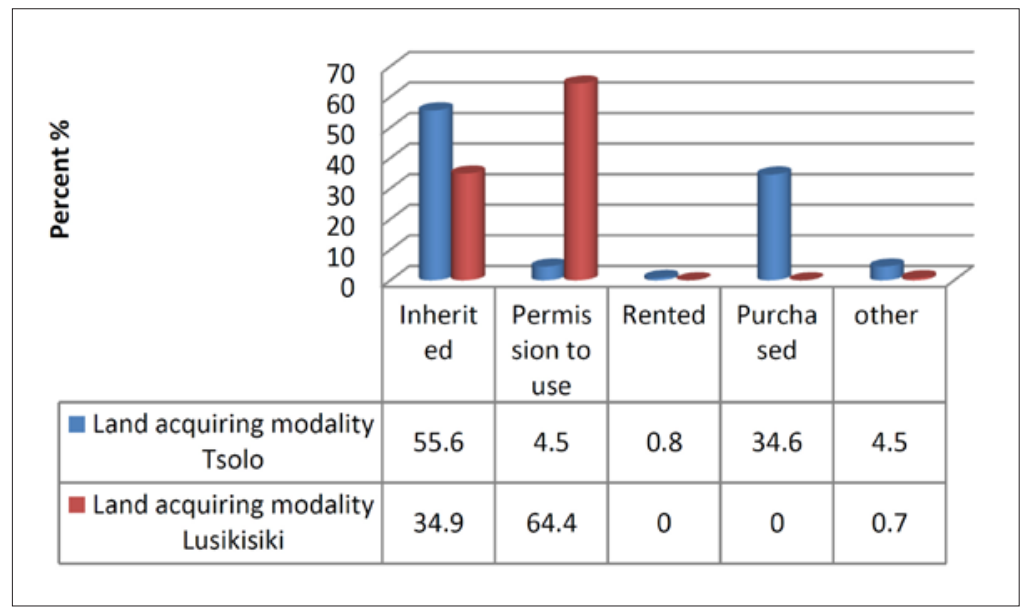

Figure 3 Land acquiring modalities in the study areas (Source: Computed from survey data)

Of the respondents in Tsolo, 34.6\% said they acquired their land through purchase. It can be useful to analyse the extent of the land market in the area. If there is an efficient land market, this can lead to optimal utilisation of land resources in the area. However, this is beyond the scope of this study. The respondents were also asked about the type of land ownership. As shown in Table 4, in Lusikisiki $67 \%$ of the respondents claimed that they had private ownership of land with title deeds. In contrast, only $34.4 \%$ in Tsolo have private ownership. Additional investigation is needed, however, to come to any conclusions given the communal ownership of land in the areas. 
Table 4 Existing land tenure type in the study area

\begin{tabular}{|l|r|r|r|r|r|r|}
\hline \multirow{2}{*}{ Existing tenure type } & \multicolumn{2}{|c|}{ Tsolo } & \multicolumn{2}{c|}{ Lusikisiki } & \multicolumn{2}{c|}{ Total } \\
\cline { 2 - 7 } & \multicolumn{1}{c|}{$\%$} & $\mathrm{~N}$ & $\%$ & $\mathrm{~N}$ & $\%$ & $\mathrm{~N}$ \\
\hline Own with title deed & 34.4 & 44 & 66.9 & 95 & 51.5 & 139 \\
\hline $\begin{array}{l}\text { Owned by parents or } \\
\text { relative but with user right }\end{array}$ & 20.3 & 26 & 8.5 & 12 & 14.1 & 38 \\
\hline Own without title deed & 37.5 & 48 & 23.9 & 34 & 30.4 & 82 \\
\hline Community ownership & 6.3 & 8 & .7 & 1 & 3.3 & 9 \\
\hline Other & .8 & 1 & .0 & 0 & .4 & 1 \\
\hline Total & 100.0 & 128 & 100.0 & 142 & 100.0 & 270 \\
\hline
\end{tabular}

Source: Computed from survey data

The respondent farmers were also asked to list major problems in getting farmland in their localities. Some of the problems listed, among many, included gender bias in favour of males, being single (i.e. unmarried children are not entitled to inherit land), and corrupt land distribution practices by local chiefs. These problems need to be addressed for the efficient utilisation of land in the areas.

\section{Social capital in the study areas}

Social capital has become a critical issue in agricultural development as it plays an important role in collective action, such as management of common resources and collective marketing (Njuki, Mapila, Zingore \& Delve, 2008). At the farmer level, although there are many factors that influence adoption and use of agroforestry technologies, studies have shown that rural communities characterised by strong social capital have faster rates of technology diffusion and improved environmental management (Woolcock \& Sweetser, 2007). This is because social capital may be the most important resource available for poor communities that are often burdened with low incomes, poor education, and few material and financial assets (Woolcock \& Sweetser, 2007). To observe the impact of social capital on the adoption of agroforestry technologies in the study areas, dummy variables for the household's membership in a group organisation and for the level of trust in local institutions were included in the survey. Most of the respondents are members of religious associations (29\%) (see Figure 4). However, membership in religious associations does not contribute positively towards agroforestry technology adoption in the study areas. This requires further investigation. The other variable for social capital in this study was the respondent's trust in local organisations and institutions which positively contributes towards adoption of agroforestry technology. 


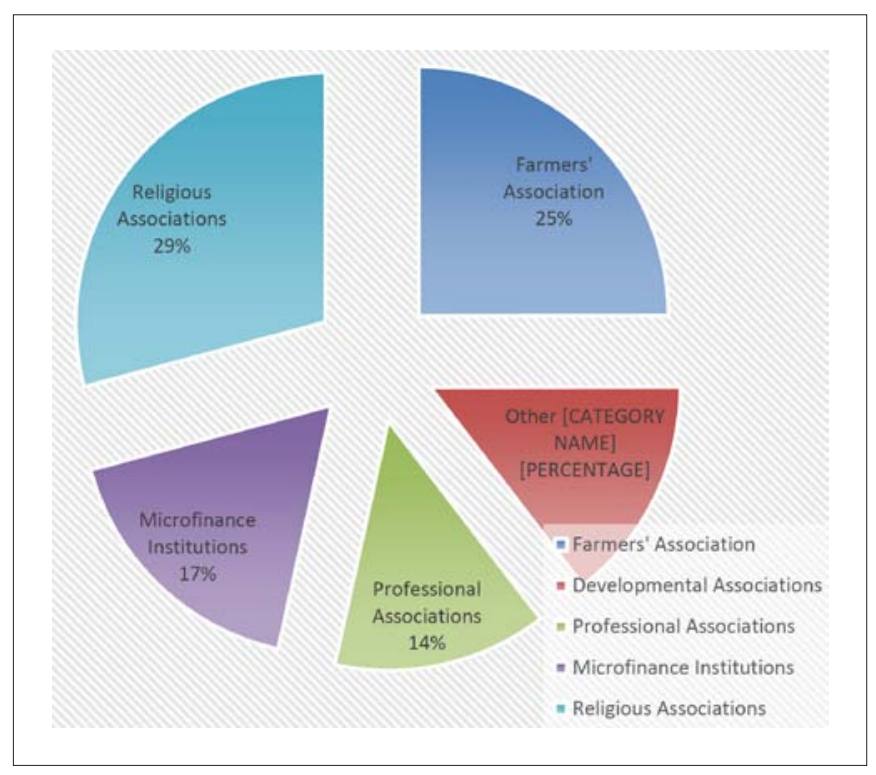

Figure 4 Types of membership among agroforestry adopting farmers (Source: Author, estimated from survey data)

\section{Institutional Aspects of Agroforestry in the Study Areas}

As summarised in Table 5, there are seven assertions to assess the institutional aspect of agroforestry in the study areas. The respondents were asked to confirm those assertions using a scale of five: strongly disagree (5), disagree (4), no opinion (3), agree (2), and strongly agree (1).

Table 5 Measures of institutional aspects of agroforestry in the study areas

\begin{tabular}{|l|l|c|c|c|c|c|}
\hline Assertions/hypothesis & Statistics & $\begin{array}{c}\text { Strongly } \\
\text { agree }\end{array}$ & Agree & $\begin{array}{c}\text { No } \\
\text { opinion }\end{array}$ & Disagree & $\begin{array}{c}\text { Strongly } \\
\text { Disagree }\end{array}$ \\
\hline \multirow{3}{*}{$\begin{array}{l}\text { All the stakeholders are working } \\
\text { jointly in promoting agroforestry } \\
\text { or forestry }\end{array}$} & Frequency & 29 & 86 & 26 & 27 & 53 \\
\cline { 2 - 8 } & Percent & 9.7 & 28.7 & 8.7 & 9.0 & 17.7 \\
\cline { 2 - 8 } & $\begin{array}{l}\text { Valid } \\
\text { Percent }\end{array}$ & 13.1 & 38.7 & 11.7 & 12.2 & 23.9 \\
\cline { 2 - 8 } & $\begin{array}{l}\text { Cumulative } \\
\text { Percent }\end{array}$ & 13.1 & 51.8 & 63.5 & 76.1 & 100.0 \\
\hline \multirow{2}{*}{$\begin{array}{l}\text { Agroforestry practices are } \\
\text { promoted by the Department of } \\
\text { Agriculture and Forestry }\end{array}$} & Frequency & 39 & 93 & 8 & 24 & 42 \\
\cline { 2 - 8 } & Percent & 13.0 & 31.0 & 2.7 & 8.0 & 14.0 \\
\cline { 2 - 8 } & $\begin{array}{l}\text { Valid } \\
\text { Percent }\end{array}$ & 18.9 & 45.1 & 3.9 & 11.7 & 20.4 \\
\cline { 2 - 8 } & $\begin{array}{l}\text { Cumulative } \\
\text { Percent }\end{array}$ & 18.9 & 64.1 & 68.0 & 79.6 & 100.0 \\
\hline
\end{tabular}




\begin{tabular}{|c|c|c|c|c|c|c|}
\hline Assertions/hypothesis & Statistics & $\begin{array}{c}\text { Strongly } \\
\text { agree }\end{array}$ & Agree & $\begin{array}{c}\text { No } \\
\text { opinion }\end{array}$ & Disagree & $\begin{array}{l}\text { Strongly } \\
\text { Disagree }\end{array}$ \\
\hline \multirow{4}{*}{$\begin{array}{l}\text { Agroforestry helps reduce } \\
\text { poverty }\end{array}$} & Frequency & 152 & 50.7 & 64.1 & 64.1 & 152 \\
\hline & Percent & 66 & 22.0 & 27.8 & 92.0 & 66 \\
\hline & $\begin{array}{l}\text { Valid } \\
\text { Percent }\end{array}$ & 5 & 1.7 & 2.1 & 94.1 & 5 \\
\hline & $\begin{array}{l}\text { Cumulative } \\
\text { Percent }\end{array}$ & 6 & 2.0 & 2.5 & 96.6 & 6 \\
\hline \multirow{4}{*}{$\begin{array}{l}\text { Agroforestry can meet the } \\
\text { household demand }\end{array}$} & Frequency & 33 & 46 & 10 & 12 & 11 \\
\hline & Percent & 11.0 & 15.3 & 3.3 & 4.0 & 3.7 \\
\hline & $\begin{array}{l}\text { Valid } \\
\text { Percent }\end{array}$ & 29.5 & 41.1 & 8.9 & 10.7 & 9.8 \\
\hline & $\begin{array}{l}\text { Cumulative } \\
\text { Percent }\end{array}$ & 29.5 & 70.5 & 79.5 & 90.2 & 100.0 \\
\hline \multirow{4}{*}{$\begin{array}{l}\text { Agroforestry practices decrease } \\
\text { the land for other uses }\end{array}$} & Frequency & 4 & 14 & 10 & 34 & 57 \\
\hline & Percent & 1.3 & 4.7 & 3.3 & 11.3 & 19.0 \\
\hline & $\begin{array}{l}\text { Valid } \\
\text { Percent }\end{array}$ & 3.4 & 11.8 & 8.4 & 28.6 & 47.9 \\
\hline & $\begin{array}{l}\text { Cumulative } \\
\text { Percent }\end{array}$ & 3.4 & 15.1 & 23.5 & 52.1 & 100.0 \\
\hline \multirow{4}{*}{$\begin{array}{l}\text { The existing tenure system } \\
\text { disfavours promotion of } \\
\text { agroforestry in the study areas }\end{array}$} & Frequency & 8 & 19 & 9 & 31 & 22 \\
\hline & Percent & 2.7 & 6.3 & 3.0 & 10.3 & 7.3 \\
\hline & $\begin{array}{l}\text { Valid } \\
\text { Percent }\end{array}$ & 9.0 & 21.3 & 10.1 & 34.8 & 24.7 \\
\hline & $\begin{array}{l}\text { Cumulative } \\
\text { Percent }\end{array}$ & 9.0 & 30.3 & 40.4 & 75.3 & 100.0 \\
\hline \multirow{4}{*}{$\begin{array}{l}\text { Overall, the adoption of } \\
\text { agroforestry practices has } \\
\text { positively affected the } \\
\text { household's livelihoods }\end{array}$} & Frequency & 13 & 40 & 14 & 6 & 3 \\
\hline & Percent & 4.3 & 13.3 & 4.7 & 2.0 & 1.0 \\
\hline & $\begin{array}{l}\text { Valid } \\
\text { Percent }\end{array}$ & 17.1 & 52.6 & 18.4 & 7.9 & 3.9 \\
\hline & $\begin{array}{l}\text { Cumulative } \\
\text { Percent }\end{array}$ & 17.1 & 69.7 & 88.2 & 96.1 & 100.0 \\
\hline
\end{tabular}

Source: Author, computed from survey data

With reference to the results summarised in Table 5, when we consider the assertion that 'all the stakeholders are working jointly in promoting agroforestry or forestry' with regard to the extreme values using a valid percentage as a point of comparison, most of the respondents did not support this. This means that stakeholders working to promote agroforestry practices in the localities do not work jointly and do not have a common strategy towards promoting 
agroforestry practices. The second assertion 'agroforestry practices are promoted by the Department of Agriculture and Forestry' was also not supported. This implies that the line departments in charge of prompting agroforestry are not working to meet the expectations of the respondents. The next assertion which stated that agroforestry helps to reduce poverty was inconclusive. There was also not enough evidence to accept the fourth and the fifth assertions. This means that agroforestry practices thus far do not meet household demands for various products and services. However, the argument that agroforestry will reduce the land available for other alternative agricultural uses was not supported by the data. The sixth assertion that the existing common tenure system (i.e. communal ownership of land) discourages the adoption of agroforestry practices was not accepted. The last assertion was also strongly rejected by the respondents which implies that, in general, the adoption of agroforestry practices has not positively affected the livelihoods of households in the study areas. This finding corroborates with the study by Sahoo and Wani (2019) for rural India. In addition, some of these assertions are also verified by the empirical results discussed in the next section.

\section{Empirical results}

\section{Logistic regression result on institutional factors}

The explanatory variables selected as institutional variables in this study included: women's access to land, participation in religious associations, information and technical knowledge exchange among farmers, participation trends in groups or organisations, and trust in local organisations or institutions. Incentive mechanisms can be part of institutional setup in a given society, however, in this study these two categories of factors affecting agroforestry adoption were treated separately.

As shown in Table 6 women's access to land significantly reduced the maximum likelihood of agroforestry technology adoption at $1 \%$ level of significance. However, the odds ratio was very low. This could be because of weak socioeconomic characteristics of female headed households. This finding is in line with the study by Oino and Mugure (2013) and studies from Malawi (Thangata \& Alavalapati, 2003) and Kenya (Sanchez \& Jama, 2002) show that female-headed households tended not to adopt agroforestry technology when compared to those headed by males. Old women, widows and female-headed households generally do not have access to secure land rights. This could be due to gender-equity issues linked to the introduction of technology to farmers, which includes land tenure issues (Oino \& Mugure, 2013). An increase in the other three variables (namely, the level of information exchange among farmers, increasing trends of participation in developmental groups or organisations, and household head's trust in local institutions) increased the likelihood of agroforestry technology adoption by higher odds ratios i.e. by more than one time when compared with the rest of the variables in the model. 
Table 6 Logistic regression results on the effects of institutional factors on the adoption of agroforestry practices

\begin{tabular}{|c|c|c|c|c|c|c|}
\hline Variable Name & B & S.E. & Wald & df & Sig. & $\begin{array}{c}\operatorname{Exp}(\mathrm{B}) \\
\text { (odds ratio) }\end{array}$ \\
\hline Women's access to land & $-1.680^{* * *}$ & .565 & 8.860 & 1 & .003 & .186 \\
\hline Participation in religious institutions & $-.295^{\star \star}$ & .128 & 5.306 & 1 & .021 & .744 \\
\hline Information exchange with other farmers & .286 & .181 & 2.509 & 1 & .113 & 1.331 \\
\hline Technical exchange with other farmers & $-.347^{\star \star}$ & .162 & 4.583 & 1 & .032 & .707 \\
\hline $\begin{array}{l}\text { Trend of participation in social groups or } \\
\text { organisations }\end{array}$ & .225 & .370 & .369 & 1 & .543 & 1.252 \\
\hline Trust in local institutions/organisations & .285 & .373 & .584 & 1 & .445 & 1.330 \\
\hline Constant & 2.896 & .734 & 15.590 & 1 & .000 & 18.105 \\
\hline $\begin{array}{l}\text { Omnibus Tests of Model Coefficients } \\
\text { - Chi-square } \\
\text { - Df } \\
\text { - Sig. }\end{array}$ & & & & $\begin{array}{l}20.5 \\
6 \\
0.00\end{array}$ & & \\
\hline$\%$ correct predictions & & & & \multicolumn{3}{|c|}{72.2} \\
\hline
\end{tabular}

Source: Estimated from survey data

\section{Logistic regression result on incentive mechanisms}

In most cases existing incentive mechanisms can promote the adoption of agroforestry technologies. Here all the variables used to assess the impact of the incentive mechanism on agroforestry adoption are qualitative variables represented by proxy or dummy variables for the purpose of logistic regression. The overall model has $74.7 \%$ correct predictions with a significant Chi-square value. Four of the variables in the regression analysis positively affect the likelihood of agroforestry technology adoption with larger odds ratios while the other three variables negatively affect the process (see Table 7). However, only two of the variables have maximum odds ratios with the positive and significant effect on the agroforestry adoption both at $1 \%$ level of significance. These variables are frequency of extension services and access to credit. The respondents with more frequent agricultural extension services adopted agroforestry practices five times more than those with no/less frequent extension services. Similarly, the respondents with access to financial credit services adopted agroforestry practices twice as much as those with no access to credit services. 
Table 7 Logistic regression results on the effect of household incentive mechanism on the adoption of agroforestry innovations

\begin{tabular}{|c|c|c|c|c|c|c|}
\hline Variable Name & B & S.E. & Wald & df & Sig. & $\begin{array}{c}\operatorname{Exp}(B) \\
\text { (odds ratio) }\end{array}$ \\
\hline Access to extension & .410 & .291 & 1.984 & 1 & .159 & 1.506 \\
\hline Frequency of extension services & $1.607^{\star \star \star}$ & .482 & 11.094 & 1 & .001 & 4.988 \\
\hline Access to credit & $.840^{\star \star \star}$ & .327 & 6.598 & 1 & .010 & 2.317 \\
\hline Prior exposure to agricultural technology & .048 & .284 & .029 & 1 & .865 & 1.050 \\
\hline $\begin{array}{l}\text { Agroforestry products harvested/services } \\
\text { generated }\end{array}$ & -.091 & .502 & .033 & 1 & .856 & .913 \\
\hline Incentive obtained & -.829 & .591 & 1.965 & 1 & .161 & .437 \\
\hline Risks involved & -.185 & .160 & 1.334 & 1 & .248 & .831 \\
\hline Constant & .614 & .595 & 1.064 & 1 & .302 & 1.848 \\
\hline $\begin{array}{l}\text { Omnibus Tests of Model Coefficients } \\
\text { - Chi-square } \\
\text { - Df } \\
\text { - Sig. }\end{array}$ & & & & $\begin{array}{l}47.3 \\
7 \\
.000\end{array}$ & & \\
\hline$\%$ correct predictions & & & & \multicolumn{3}{|c|}{74.7} \\
\hline
\end{tabular}

Source: Author, computed from survey data

\section{Conclusion and policy implications}

Previous studies in the adoption of agroforestry practices propose the need for additional research for better understanding of the role of incentive mechanisms and institutional factors. This study focuses on these factors in the Eastern Cape Province of South Africa. In the two study areas, the younger generation of farmers tend to own less than one hectare of land. The respondents were also asked how the prevailing tenure system affects the adoption process. The argument was that farmers would be reluctant to invest in their land and make efforts to conserve it if they were uncertain about future rights to use it. On the other hand, a secure tenure system could lead to better land management technologies, which would ultimately improve soil quality and boost agricultural productivity. The main conclusion from empirical studies so far has claimed that secured land rights create an essential economic incentive that enhance long-term land investment, which improves soil fertility and hence significantly influences agricultural productivity. The findings in this study do not support the hypothesis that the existing tenure system disfavours promotion of agroforestry practices in the study areas.

Among institutional variables included in this study, women's access to land significantly reduces the likelihood of agroforestry technology adoption at $1 \%$ level of significance. However, 
the odds ratio was very low. This could be due to the poor socio-economic situation of femaleheaded households. The other three variables in this model, namely, the level of information exchange among farmers, a trend towards increased participation in developmental groups or organisations, and trust of the household head in local institutions, increase the likelihood of agroforestry technology adoption by more than once if the opposite were the case.

In the second model, the variables of incentive mechanisms regressed on the dependent variable. Only two of the variables had maximum odds ratios with the positive significantly effect on agroforestry adoption at $1 \%$ level of significance. These variables were frequency of extension services and access to credit. The respondents with more frequent agricultural extension services adopted agroforestry practices five times more than those with no/less frequent extension services. Similarly, the respondents with access to financial credit services adopted agroforestry practices more than twice more than those with no access to credit services.

Relevant authorities should facilitate financial credit services and incentive schemes via various portfolios like the Comprehensive Agricultural Support Programme (CASP) for those framers with experience and willingness to promote agroforestry practices. The activities of agricultural/forestry/agroforestry extension services should continue a regular basis in consultation with local municipalities, landowners, farmers, traditional authorities, and individual households. To speed up the adoption of agroforestry practices in the study areas, the nexus between land tenure systems and other institutional variables needs to be explored further. Farmers with insecure land rights tend to be unwilling to plant trees. Improved access to land is vital to improve adoption of agroforestry practices, though not necessarily via individual title deeds. The ongoing land reform in South Africa thus should contribute towards adoption of agroforestry practices among smallholder farmers.

\section{Acknowledgements}

I would like to acknowledge Prof. Eureta Rosenberg, the Editor-in-Chief, and the anonymous referees for the valuable comments that led to significant improvements in this paper. I would also like to express my sincere gratitude to Tsolo Agricultural and Rural Development Institute in the Eastern Cape Province, South Africa, for the generous logistical support during data collection at Tsolo and Lusikisiki. The usual disclaimer applies.

\section{Notes on the contributor}

\section{Zerihun, Mulatu F.}

Tshwane University of Technology, South Africa

Dr Zerihun is a Senior Lecturer in Economics and Acting Head of Department of Economics at the Faculty of Economics and Finance, Tshwane University of Technology, Pretoria, South Africa. He has published widely in areas related to Open Economy Macroeconomics, Development Economics and Environmental Economics. 


\section{References}

Alavalapati, J.R., Mercer, D. \& Montambault, J. (2004). Agroforestry systems and valuation methodologies: an overview. In J.R. Alavalapati \& D. Mercer (Eds). Valuing Agroforestry Systems: Methods and applications. Dordrecht: Kluwer Academic Publishers.

Alavalapati, J.R. \& Nair, P. (2001). Socioeconomics and institutional perspectives of agroforestry. In M. Palo \& J. Uusivuori (Eds), World Forests, Society and Environment: Markets and polices. Dordrecht: Kluwer Academic Publishers.

Agresti, A.\& Finlay, B. (2009). Statistical Methods for the Social Sciences (4th ed). Upper Saddle River, New Jersey: Pearson Hall.

Brasselle, A-S., Gaspart, F. \& Platteau, J-P. (2002). Land tenure security and investment incentives: Puzzling evidence from Burkina Faso, Journal of Development Economics, 67(2), 373-418.

Boserup, E. (1965). The Conditions of Agricultural Growth. Aldine: Chicago.

Brown, S.E., Mille, D.C., Ordonez, P.J. \& Baylis, O. (2018). Evidence for the impacts of agroforestry on agricultural productivity, ecosystem services, and human well-being in high-income countries: A systematic map protocol. Environmental Evidence, 7, 24. doi: 10.1186/s13750-018-0136-0.

Cengiz, C. (2013). Urban ecology. In M. Ozyavuz (Ed.), Advances in Landscape Architecture. InTechOpen. doi: 10.5772/56314.

Christensen, R. (1997). Log-linear Models and Logistic Regression (2nd ed). New York: Springer.

Department of Agriculture, Forestry and Fisheries (DAFF). (2012). Agro-processing Annual brief: Looking at 2012. Retrieved from: http://www.nda.agric.za/doaDev/ side Menu/ AgroProcessingSupport/docs/Agroprocessing\%20annual\%20\%20BRIEF_final.pdf

Food and Agriculture Organisation (FAO). (2013). Advancing Agroforestry on the Policy Agenda: A guide for decision-makers (Agroforestry Working Paper no. 1 - G. Buttoud, in collaboration with O. Ajayi, G. Detlefsen, F. Place \& E. Torquebiau). Rome: FAO.

Garrity, D.P. (2006). Science-based agroforestry and the millennium development goals. In D.P. Garrity, A. Okono, M. Grayson \& S. Parrott (Eds.), World Agroforestry into the Future. Nairobi, Kenya: World Agroforestry Centre, ICRagroforestry.

Green, W. (2002). Econometric Analysis (5th ed). USA: Macmillan.

Gujarati, D.N. (2004). Basic Econometrics (4th ed). New York: McGraw-Hill.

Kabwe, G. (2010). Uptake of agroforestry technologies among smallholder farmers in Zambia. Unpublished PhD thesis, Lincoln University, Christchurch, New Zealand.

Klieštika,T., Kočišováa, K. \& Mišankováa, M. (2015). Logit and Probit Model used for prediction of financial health of company. Procedia Economics and Finance, 23, 850-855.

Lahiff, E. (2002). Land reform and sustainable livelihoods in South Africa's Eastern Cape Province. Sustainable Livelihoods in Southern Africa Research, Paper 9. Brighton: Institute of Development Studies.

Lassoie, J.P. \& Buck, L.E. (2000). Development of agroforestry as an integrated land use management strategy. In H.E. Garrett, W.J. Rietveld \& R.F. Fisher (Eds.), North American 
Agroforestry: An Integrated Science and Practice. Madison: American Society of Agronomy. pp. 1-29.

MacDicken, K.G. \& Vergara, N.T. (1990). Agroforestry: Classification and management. New York: John Wiley and Sons.

Manona, S.S. (2005). Smallholder agriculture as local economic development strategy in rural South Africa: Exploring prospects in Pondolands, Eastern Cape. Unpublished MA Thesis, University of Western Cape, South Africa.

Nair, P.K.R. (1993). An Introduction to Agroforestry. The Netherlands: Kluwer Academic Publishers.

Njuki, J.M., Mapila, M.T., Zingore, S. \& Delve, R. (2008). The dynamics of social capital in influencing use of soil management options in the Chinyanja Triangle of southern Africa. Ecology and Society, 13(2), 9.

Oino, P. \& Mugure, A. (2013). Farmer-oriented factors that influence adoption of agroforestry practices in Kenya: Experiences from Nambale District, Busia County. International Journal of Science and Research, 450-456.

Owonubi, J.J. \& Otegbeye, G.O. (2012). Disappearing forest: A review of the challenges for conservation of genetic resources and environmental management. Journal of Forestry Resource Management, 1(1/2), 1-11.

Pattanayak, S., Mercer, D.E., Sills, E. \& Yang, J. (2003). Taking stock of agroforestry adoption studies. Agroforestry Systems, 57, 173-186.

Peng, C.Y.J. \& So, T.S.H. (2002). Logistic regression analysis and reporting: A premier. Understanding Statistics, 1(1), 31-70.

Reed, M.S., Dougill, A.J. \& Taylor, M.J. (2007). Integrating local and scientific knowledge for adaptation to land degradation: Kalahari Rangeland Management Options, Land Degradation \& Development, 18(3), 249-268.

Sahoo, G.R. \& A.M. Wani, A.M. (2019). Multifunctional agroforestry systems in india for livelihoods, Annals of Horticulture, 12(2),139-149.

Sahoo, G.R, Wani, A.M. \& Satpathy, B. (2020). Greening wastelands for environmental security through agroforestry. International Journal of Advanced Research in Science \& Technology, 7(4), 35-42.

Sanchez, P.A. \& Jama, B.A. (2002). Soil fertility replenishment takes off in East and southern Africa. In B. Vanlauwe, N. Diels, N. Sanginga \& R. Merkx (Eds.), Integrated nutrient management in sub-Saharan Africa: From concept to practice. Wallingford, UK: CAB International. pp. 26-43.

Shackleton, C.M., Shackleton, S.E. \& Cousins, B. (2001). The role of land-based strategies in rural livelihoods: The contribution of arable production, animal husbandry and natural resource harvesting in communal areas in South Africa. Development Southern Africa, 18(5), 581-604.

Sibisi, S. (2011). Development Report: Prospects for South Africa's future (Overview).

Development Bank of Southern Africa.

Sileshi, G., Akinnifesi, F.K, Ajayi, O.C. \& Place, F. (2009). Evidence for impact of green fertilizers 
on maize production in sub-Saharan Africa: A meta-analysis. ICR agroforestry Occasional Paper No. 10. Nairobi: World Agroforestry Centre.

Simmons, C.S., Walker, R.T. \& Wood, C.H. (2002). Tree planting by small producers in the tropics: A comparative study of Brazil and Panama. Agroforestry Systems, 56, 89-105.

Thangata, P. \& Alavalapati, J. (2003). Agroforestry adoption in southern Malawi: The case of mixed intercropping of Gliricidia sepium and maize. Agricultural Systems, 78, 57-71.

Van Noordwijka, M. (2019). Integrated natural resource management as pathway to poverty reduction: Innovating practices, institutions and policies. Agricultural Systems, 172, 60-71.

Woolcock, M. \& Sweetser A.T. (2007). Social Capital: The bonds that connect. Manila, Philippines: Asian Development Bank.

Zerihun, M.F. (2014). A socioeconomic analysis of factors that affect the adoption of agroforestry technologies in the Eastern Cape Province of South Africa. Unpublished doctoral thesis, Business School, Tshwane University of Technology, Pretoria, South Africa. 
